\title{
URBANIZATION-METROPOLIZATION AND HOLIDAY RESORTS ON THE NORTHEAST COAST OF BRAZIL
}

\author{
urbanização-metropolização e vilegiatura no litoral nordestino brasileiro
}

\author{
Alexandre Queiroz Pereira*
}

\begin{abstract}
Resumo
O gosto e, consequentemente, a realização das práticas marítimas engendram estruturas diversas e resultam em espacialidades urbanas em função do lazer no contexto metropolitano. Aqui, as reflexões abordam a costa nordestina brasileira como caso de estudo, todavia não deixam de estabelecer conexões com outros espaços nacionais e internacionais. Parte-se da construção empírico-conceitual do processo e são estabelecidas duas dimensões de análise: a dimensão da morfologia urbana e a das práticas sociais.
\end{abstract}

Palavras chave: Periurbanização; Morfologia urbana; Lazer; Segundas residências.

\begin{abstract}
The preference for and consequent exercise of maritime practices give birth to diverse structures and result in leisure focused urban spaces in the metropolitan context. The reflections here deal with the Northeast coast of Brazil as a case study; however they do not avoid making connections with other national and international spaces. The starting point is the empirical-conceptual construction of the processfrom which dimensions of analyses are established: the dimension of urban morphology and that of social practices.
\end{abstract}

Key words: Peri-urbanization; Urban morphology; Leisure; Second homes.

\section{Resumen}

El gusto y, consecuentemente, la realización de las prácticas marítimas engendran estructuras diversas y resultan en espacialidades urbanas en función del ocio en el contexto metropolitano. Aquí, las reflexiones abordan la costa del nordeste brasileño como caso de estudio, pero no dejan de establecer conexiones con otros espacios nacionales e internacionales. Se inicia a partir de la construcción empírico-conceptual del proceso y son establecidas dos dimensiones de análisis: la dimensión de la morfología urbana y la de las prácticas sociales.

Palabras clave: Periurbanización; Morfología urbana; Ocio; Segundas residencias. 


\section{INTRODUCTION}

The process of contemporary urbanization is marked by the interaction between forms and contents with distinct temporal densities. Old and new city functions associate with old and new fixtures, leading to the (re)production of heterogeneous and in a contradictory but simultaneous way homogenous urban spaces (under determined measures). Therefore, any study which explores only one dimension of urban functions is increasingly less able to explain the aforementioned diversity.

In discussing theses about urbanization, Brenner (2014) indicates three series of marked spatial transformations in the urban context since the start of the millennium: i) the appearance and explosion of new, larger morphologies, which crossover urban and rural spaces; ii) the many varied state actions aiming to give urban spaces characteristics which are attractive for national, international and transnational investments; iii) the transformation of the metropolis into a strategic space for the territorial conflicts between distinct social segments. Both the first and the second items, emphasized by Brenner, are transformed into important themes in this article.

As one observes the urban in the twenty-first century, the metropolization of space has evidently become a scientific frontier to explore. Consequently, metropolitan spaces unfold themselves through an increase in density and functional, property and demographic dispersals. The contribution of metropolitan studies touches on the concept of the existence of agents promoting restructuring (market, science, technology) but also includes creators of specific (and even peculiar) conditions: inherited urban functions, urban sites, and regional and local political relationships.

In discussing the characteristics of metropolized spaces Lencioni (2013) points to the initial evidences provided by the scenery as "[...] to the extent that one becomes more distant from the spaces where there is a greater density of persons, goods and flows, the non-metropolized spaces impose themselves upon metropolized spaces" (p. 19).

It is important to emphasize the relevance and the distinction of preponderant phenomena, in determined scales, in bringing about the process of metropolization of space. For this purpose this article seeks to contribute by proposing an emphasis on the relationship between urbanization, metropolization and leisure practices in urban agglomerations located on oceanic coasts. The preference for and consequent carrying out of these practices give rise to diverse structures and result in metropolitan leisure spaces. The foundational principle is the understanding of the journey and the temporary stay based upon leisure as an urban and maritime practice. In current times, the holiday resort represents the totality of the complex of social practices provided by the temporary stay normally linked to leisure. Geographical studies with this perspective, rather than distinguishing between tourists and those at holiday resorts, focus their analyses and understanding on the territorial impacts on the "nodes" promoted by this urban fixation.

Hence, rather than producing a methodological path close to that of the geography of tourism, or a new branch (geography of leisure) it is wise to follow an urban geography analysis which emphasizes summer resorts, understood as both bringing about the urbanization process and being brought about by it. The intention is to understand the capacity of this practice in the organization of spaces and in establishing relationships, inserting them in the composition of metropolitan spaces.

This article focuses on the northeast coast of Brazil as a case study; however it also establishes connections with the specialized literature in other national and international spaces. However, care is taken not to establish direct comparisons, considering both the social and spatial continuities and discontinuities. After the initial considerations, this article is developed in three moments: the first moment documents the issue of a temporary stay at the seafront and its relationship with the city, defending its condition as an urban function; the intermediary moment emphasizes maritime leisure practices in the face of contemporary urban transformations, especially in the light of the metropolization of space; while the last subsection of this text draws out two analytical dimensions as a support of studies of coastal urbanization, that is, the dimension of urban morphology and social practices. 


\section{MARITIME HOLIDAY RESORTS AND THEIR URBAN DIMENSION: INITIAL TOPICS}

The temporary stay, especially in coastal spaces is a catalyst, it synthesizes and causes all the diverse leisure and rest practices. To meet the needs of the crowds which move between places, locations and subspaces are reconfigured, "modernized", or better, urbanized. This happens because the origin, formation and daily life of the vacanciers is based on the city and, especially, the urban. Currently, it is the spaces next to the sea that have passed through these transformations most intensely, as they are globally desired as holiday resorts and/or housing.

Among many locations, urban society treats the beach as the favored space for a temporary stay for leisure purposes. Boyer (2008) considers Brighton, on the English coast, still in the nineteenth century, as the first modern beach formed as a result of the enjoyment of the elite classes of that country, later transformed into a beach also for the less noble segments of British society. The process of organization of leisure complexes on the coast marked a golden age in coastal holiday resorts in Europe. Undoubtedly, this movement promoted such socio-cultural activity to the urban function. This became a prototypical movement for the reinvention of urban use on the coastal boundaries at median latitudes, especially in the Mediterranean and Florida.

Such a context is directly associated with the ascension of industrialist values in the composition of Western civilization, a moment in which urban society constitutes itself as a virtuality (LEFEBVRE, 1999). A series of transformations is visualized, among them the redefinition of the perception of the beach, transfigured into a social space. The territory of emptiness indicated by Corbin (1989) became a territory for potential urbanization. City dwellers walk on the beach, live by the beach, rebuilding it to meet leisure and well-being needs. Promenades were built along the beaches of nineteenth century cities, and seaside walks dominated. By the first quarter of the twentieth century automobiles conquered the avenues along the beachfront (DIBIÉ, 1993). From then on coastal cities embraced their seaside.

Beaujeau-Garnier (1963) in his Traité de géographie urbaine recognizes the character of urban function in leisure. The author describes various types and indicates the villes de bains de mer as fabulous examples of urbanization based upon the demand for seasonality and leisure. If the process of a relationship between urbanization and maritime holiday resorts is evident, through the induction of the first upon the second, other writings, specifically Pereira (2014), identified the practice of leisure as a potential cause for the dissemination of urban forms and contents. There is therefore a resemblance with the characterization elaborated by the French author in the 1960s.

Ces villes de récréation relaient em quelque sorte les autres formes de vie urbaine; elles sont donc particulièrement nombreuses dans les pays où le réseau urbain est dense, les agglomérations fortes et le niveau de vie élevé (BEAUJEU-GARNIER, 1963, p. 178).

The locations linked to these leisure activities of urban populations reorganize themselves continuously, so that the predominant functions and sceneries become clear: second homes, hotels, restaurants, condominiums, resorts, marinas, shops and services. The variation in the concentration of these elements contributed, during the twentieth century, to the formation of distinct coastal sceneries redefined by city dwelling populations' desire for leisure. This process became an "affluent" of the general process of urbanization, due both to the emergence of the vacanciers (originating from medium sized and large urban agglomerations) and the social spatial transformations in the formation of health resorts. In Lefebvrian terms an extension occurs in the urban fabric.

In the process of increasing the value of coastal spaces, urban characteristics are added to the scenery following the same rhythm of the incremental growth of the flow of people and investments. The actions of the initial production of the locations follow different paths which converge in the heterogeneity of subjects that is also a mark of the mass standardization of the process. In this sense it is possible to mention the participation of individual real estate entrepreneurs (gatekeepers), business groups and even trail brazing users disinterested in monetary gain. From a particular moment 
on, all act simultaneously, with or without a conflict of interests. With the institution of maritime holiday resorts, locations go through transformations which are indicative of urbanization, namely:

a) New property dynamics: distinct uses are added to properties, converging in the increase in their value and the creation of a real estate market based on exchange value. The concept of rarity has a direct impact, leading to a relative increase in prices. The division of land appears and expands, normally regulated by legislation specific to urban spaces. At the same time, residential constructions multiply themselves in varied forms: residences for seasonal use by a single family, residential units in horizontal and vertical condominiums and tourist property complexes (which have all the previous forms in a planned resort). All these elements contribute to the implementation and/or densification of the urban morphology in the locations.

b) Diversification in the urban division of labor: transformed into an economic activity, these forms of leisure require, beyond physical infrastructure, a range of services and shops. In this sense, there is a progressive dislocation of labor posts towards the tertiary sector at locations next to the sea. This situation occurs due both to the arrival of experienced business groups and the formation of local entrepreneurs. The seasonality of vacanciers interferes in the quantitative distribution of labor posts and the flexibility of functions during the seasons. Public and private organizations train professionals using technical training resources based on external and international standards of service provision.

c) Positive demographic dynamic: due to the insertion of new economic activities and the creation of jobs, these spaces become receptive to migratory flows. A common phenomenon for activities marked by spatial mobility such as holiday resorts and tourism is the transformation of vacanciers into residents. In this way, beyond vegetative and migratory growth such spaces display quantitative growth with regards to the size of their population.

d) Cultural contacts and establishing customs: the social interaction between vacanciers and those living in the receiving spaces promotes, as well as commercial relations, symbolic and cultural exchanges. Urban fashions and customs are implemented in these locations. These influences are notable in terms of clothing, the use of electronic equipment, the architecture of homes, leisure activities and even every day verbal expressions.

e) Urban legal institutions: due to those aspects already mentioned, coastal spaces are invariably regulated by local legislation that considers them, generally, as urban zones and/or areas. Laws concerning zones, land usage and occupancy, construction codes and postures are examples of legal instruments regulating access to these spaces and their transformation. At the same time, a structure is created for collecting taxes, especially those on the ownership of properties and the market transfer of goods. This legislation is an important condition for the spread of the urban fabric, as it indicates priority areas for expansion. On the other hand, due to natural characteristics, environmental protection legislation has extended limitations to land use across the world, having its main justification in vulnerability to erosive processes and the need to concerve native flora and fauna.

Highlighting these effects demonstrates the role of holiday resorts in expanding the urban fabric. As a result the localities, the maritime leisure villas move from isolation to integration in a complex whole: the metropolis.

\section{THE UNFOLDING OF THE METROPOLIZATION OF MARITIME LEISURE IN THE NORTHEAST OF BRAZIL}

In the twenty-first century, the metropolization of space is attuned with the formation of urban agglomerations which are not necessarily continuous in terms of space, and with distinct levels 
of integration. This integration is evidenced by the density of infrastructure (production, transport and energy, among others) generally articulated in networks. This territorial whole is distributed heterogeneously as the contemporary metropolis is a complex of functions, that is to say, subspaces.

As argued above the formation of metropolises occurs through the conjugation of metropolized and non-metropolized spaces (LENCIONI, 2013). However, the most important question addresses the issue of which are the most and least efficient vectors and/or social activities in the current production of spaces and metropolitan networks. In this sense there is little doubt concerning the roles played by the diffusion of different industrial sectors and traditionally, that of residential properties, associated to the creation of large scale commercial centers (mainly outlets and shopping malls). Notwithstanding the desire for leisure of both the masses and the elites there is a strong potential to extend the urban fabric and generate an interconnection between territories. In this way, the city, in its traditional formation, on its own no longer has all the desires and possibilities regarding leisure.

The process of metropolization- and the metropolis itself- opens up a range of options. The inclusion of distinct places occurs as points in a network, destined for temporary leisure stays. Analyzed by Beaujeu-Garnier in the 1960s, this context is not exclusive to the current times.

Chaque grande agglomération a ainsi ses annexes villégiatures où la famille passe ses longues vacances, où le chef de famille se rend pour le week-end, et c'est surtout vrai quand on est proche de la côte, où les plages deviennent facilement des petites villes (BEAUJEU-GARNIER, 1963, p. 432).

Rather than being an exception, the urbanization of spaces for leisure functions (and for holiday resorts) is common in the Canadian, Irish, Australian, New Zealander, South African, Spanish and Scandinavian cases (HALL; MULLER 2004). In many situations this process is understood as strategic for the development of the receiving regions, especially motivated by tourism and the concentration of second homes, both for vacation and weekends. Specifically for the coast, studies by Roca et al (2009) and Latorre (1989) discuss the influence of large cities in the formation of new urbanized areas in Portugal and Spain respectively.

Once again there are two variables in the process: a social variable and a spatial one. The first variable refers to the mass increase in demands for practices near to holiday resorts and coastal tourism (PEREIRA 2014); the second refers to the urbanization of "underdeveloped" countries during the second half of the twentieth century. The demographic growth associated with a certain diversification of the productive base (via state interventions- public policies) conditioned the formation of metropolises in subnational regions. In this context and according to a tendency in the Western World, coastal spaces next to the metropolises are gradually incorporated.

In the Brazilian case, with few exceptions, coastal location is a relevant factor in the formation of the main national metropolises. In this process of constitution, the expansion of leisure zones on the coast also has a strong expression, especially those located in the states of Rio de Janeiro and São Paulo. In the first case it is the state capital itself which is recognized for its immanent coastal nature. In the twentieth century the image of the archetypal dweller of Rio de Janeiro was formed, characterized, among other images, as a lover of the sea and the maritime. There are direct impacts, both in the urban beaches (among the most well known in the world) and in the other coastal spaces in the whole state of Rio de Janeiro. In the case of the state of São Paulo, the area surrounding the port of Santos was formed with strong links to the demands of the national metropolises, becoming the densest urban "outskirts" produced for maritime leisure in the country. On the main extended holidays, including the New Year celebrations, hundreds of thousands of residents of the city of São Paulo go down the mountain range to the coast, towards the beaches of Santos, Granjá, Praia Grande, São Vicente and Bertioga, among others.

The northeast coast of Brazil has three important metropolitan regions (Salvador, Recife and Fortaleza) and is a byword for the national tourist coast. Beginning in the 1990s, the image of a tropical paradise, with sandy, sunny beaches and warm waters has been consolidated permitting the insertion of maritime resorts as new agents in coastal spaces previously restricted to local city 
dwellers (autochthons). Currently, holiday resort vacanciers from other regions and other countries (non-native) are added to traditional flows. Through these flows the notion of tourist metropolization is constituted.

Maritime resorts are reproduced as they constitute notable peri-urban areas related to large coastal agglomerations, especially metropolises. This specific peri-urbanization defines a characteristic form of metropolization which unfolds in normative, socio-economic and real estate transformations in coastal spaces. It is important, at this moment, to indicate theoretical and methodological elements capable to explain this process in the Northeast of Brazil. The starting point is the empirical and conceptual construction of the process which establishes two analytical dimensions: the dimension of urban morphology (norms-urbanism-real estate) and that of social practices. Empirical evidence, the main social agents and the key concepts stand out as tools to explain the content of these dimensions.

\section{URBAN MORPHOLOGY: PROPERTY, URBANISM AND NORMS}

Urban morphology is understood as a key indicator of socio-territorial transformations in coastal spaces. Its formation happens in a process which is linked to property dynamics, regulated by urban planning, that is urbanistic technical knowledge. In the case of resort spaces in the metropolis, the demand for maritime leisure practices organizes the territory through the installation of a mobility infrastructure (coastal highways) and, mainly, in a set of services and properties which provide the conditions for a temporary stay.

Urban morphology is the network itself materialized. The central point is the city which originates the metropolitan region and, from it, a process of coastal peri-urbanization proceeds, spread across the world, presenting general characteristics as indicated by Tenán (1969).

La urbanización de las zonas periféricas y de los ambientes rurales circundante se xtiende formas de vida urbana, sin que ileguen a crearse estructuras urbanas. Vastos espaciosinorgánicos se incorporan a la urbe, aboliendo das fronteras entre lo urbano y lo rural. Un 'habitat' de tipo urbano se dispersa y desparrama sobre território aún no urbanizado, dando lugar a essas zonas de calificacióndudosa: 'suburbanas', 'interurbanas', 'exurbanas', 'rurbanas', etc., en las que se pierde el concepto tradicional de ciudad, la cual se haceasí difícilmente abarcable y comprensible em forma y dimensión por los habitantes. Aquarone ha explicado así la formación de estes nuevo ente semiurbano, extendido ampliamente, que puede englobarem su trama várioscentrosantiguosmás o menos importantes y más o menosconcentrados (TERÁN, 1969, p. 130).

In the case of the Northeast peri-urbanization is the expression that is able to clarify the incorporation of the beach areas into the urban, or better metropolitan, dynamics. Territorially, the formation of nucleuses of occupation and the insertion of technical systems into the territory provide a multi-faceted, disfigured urban morphology (LENCIONI, 2013). The tourist metropolization of the Northeast, explained by Dantas (2015), is yet another indicator of the socio-spatial diversity of this region in this beginning of century. In terms of planned and moderated actions, the metropolization of the coast is marked by a linear and fragmented urban morphology, made more dynamic by seasonal movements.

This linearity and fragmentation are explained, among other situations by the natural location, the road transport matrix (which runs parallel to the coastline) and the spontaneity of the formation of coastal locations. The seasonality is explained according to the regulation of the use of time and space in the urban life style which separates specific periods and spaces for the development of certain practices, among them leisure. This comes fundamentally as a consequence of islands of occupation, considered fragments of the metropolis, as shown in the model exposed in the following figures. 
In all the urban agglomerations, considered metropolitan regions in the Northeast, spatiality goes beyond the municipal polygons. The territories produced in terms of leisure form a network which is internal to the metropolises and are characterized by having a discontinuous urban morphology, but are integrated through airports and coastal roads. Although it is at the interstice of other processes and often understood solely as a consequence, the spatial occupation of holiday resorts is efficient in the production of sub-regions regulated by the logic of the emitting urban agglomerate.
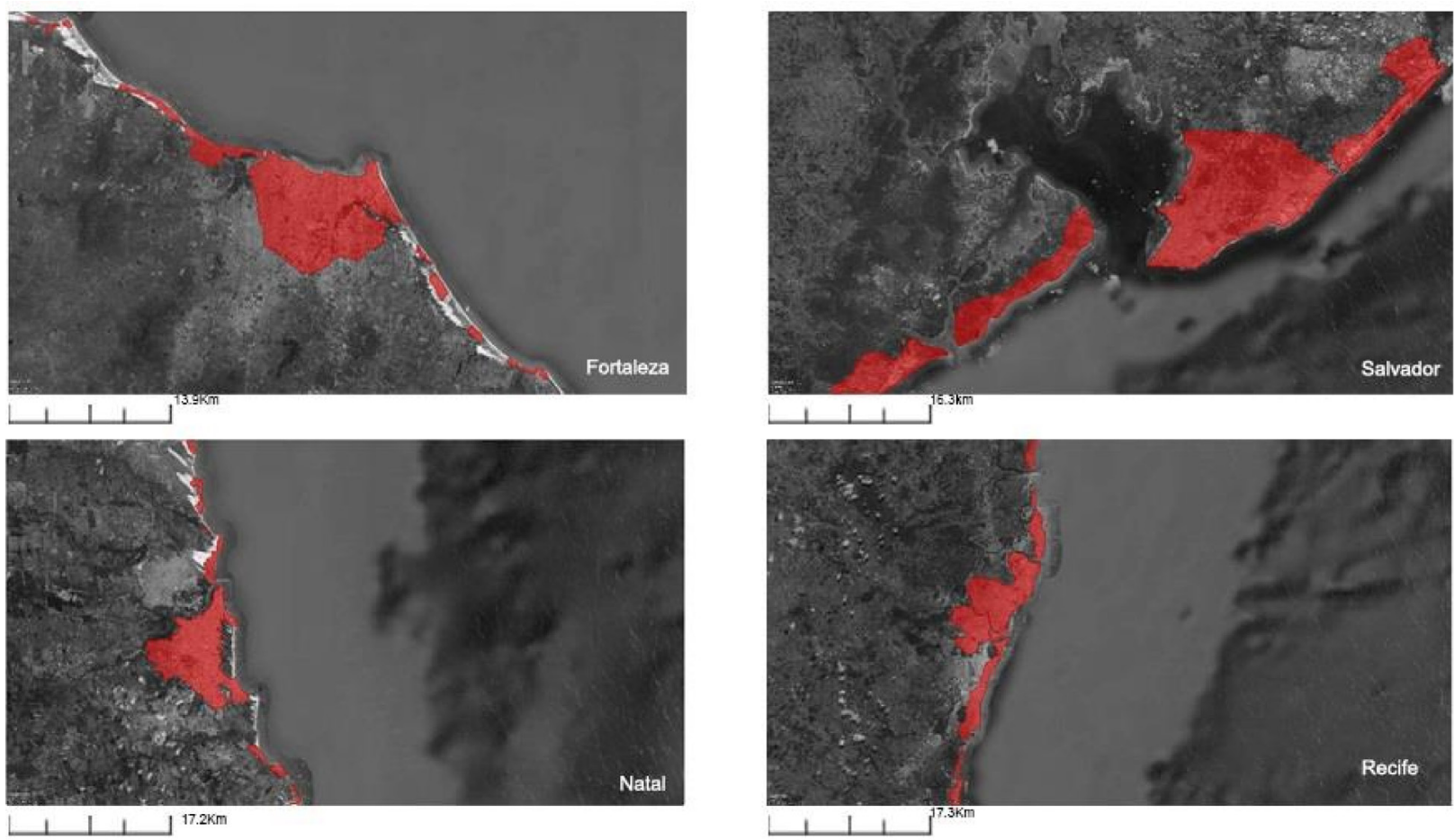

Figure 1 - The urban coastal metropolitan sprawl in Fortaleza, Natal, Recife and Salvador

This fragmentation and linearity can normally be explained by the increase in value of the land closest to the sea and by the invention of new places suitable for recreational activities. Therefore, in the peri-urban space a mosaic consisting of resorts, environmental protection, uncultivated estates, small fishing and extractive villages and even illegal and pauperized settlements is formed. Thus, heterogeneity is present in these spaces that are being metropolized.

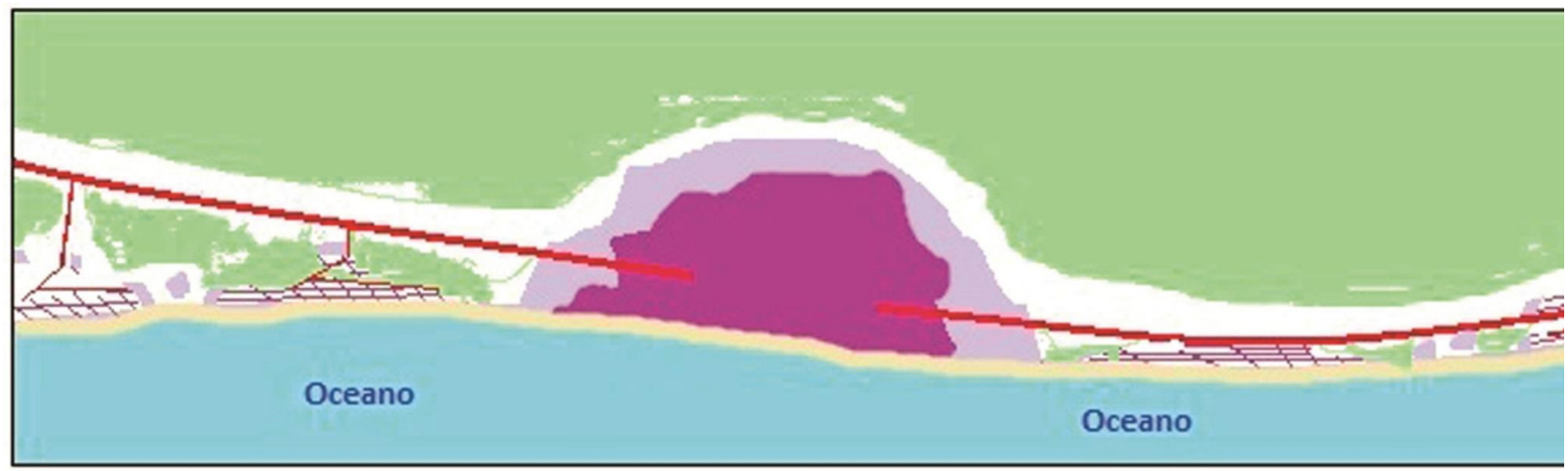

Main urban sprawl

Directly associated urban sprawl

Urbanized beach

Rare or non-existent occupation 
For each metropolitan unit a central hub and a set of articulated maritime leisure estates are formed. A network is established, consolidated by centrifugal and centripetal movements. The hub city attracts visitor flows and holds the brand, the positive attractive image, the hotels, the rental flats and the exciting nightlife. It has globalized specialized services. The peri-urban space contains the beach, a lower population density, the environmental quality and the resort. The hub city has company headquarters, planning, resources, while the products, apartments, homes and land units are on the beach. The hub city and the resort nodes form the network of places destined for leisure and become ever more evident as the emblem of the metropolises of the Northeast.

In the 1990s the maritime resort leisure nodes of the metropolitan network were formed through the construction of second homes, starting with locations with small villages with traditional communities (mainly fishing). In the 2000s, international demand and the offer of new real estate products facilitated the installation of tourism and property complexes. These are megaprojects with a mixed use, characterized by a diversity of activities, including the letting and sale of properties destined for maritime leisure. They are capable of attracting national and international flows of holidaymakers, consuming areas of more than one hundred hectares. Dozens of such enterprises are concentrated in the metropolitan areas of the Northeast and are responsible for two sets of changes in the production of metropolitan coastal space. Firstly, the construction of new typologies, (resorts, hotel condos, flats and condominiums) prioritizes the space surrounding the hub city, leading the State to complement the process of upgrading the infrastructure in the coastal metropolitan space (mainly the coastal transport routes). Secondly, the location of these enterprises does not necessarily occur in places consolidated by generic tourist activities, possibly being discontinuous and thus forming self-sufficient closed spaces (offering all that is necessary for the tourist's stay). The space which was formerly regulated by spontaneous uses becomes, due to public investment and the development of tourist property complexes, induced use. The magnitude of flows, spatial transformations, redefinition of places and formation of new territorial networks is increased (figures, 3, 4, and 5).

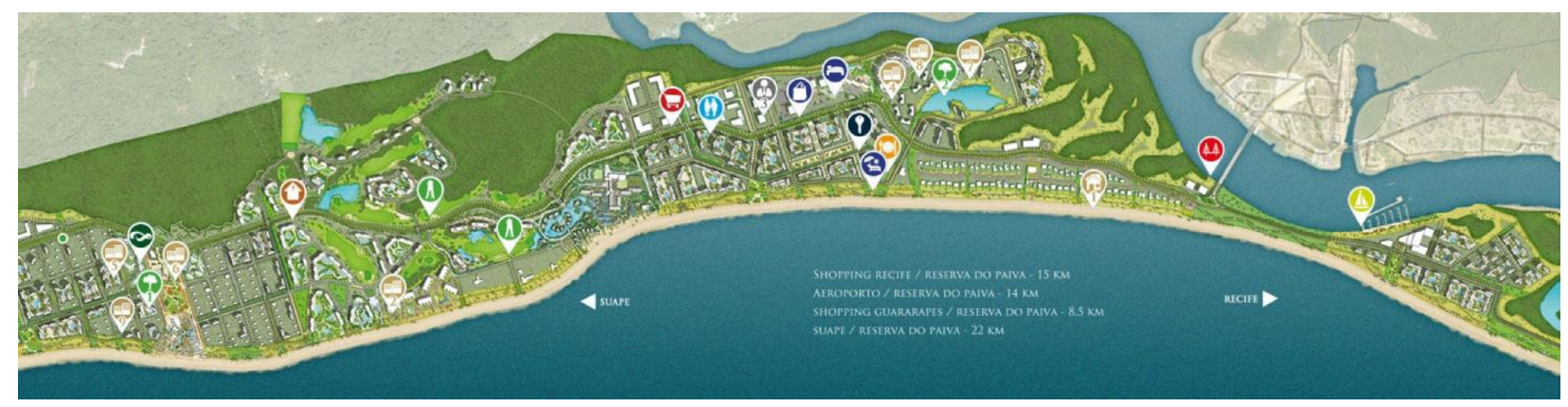

Figure 3 - Masterplan of the tourist property complex Reserva do Paiva. Cabo de Santo Agostinho - Recife.

One notable transformation is the significant increase of new property developments, especially those for occasional use (IBGE), which are very similar to what are considered second homes. According to data from the last censuses there has been an increase in the number of such homes, especially since the 1990s. It is believed that in the next counts and with the construction of complexes and their internal enterprises (condominiums, land shares) the growth in the number of second homes will remain (Table 1). 


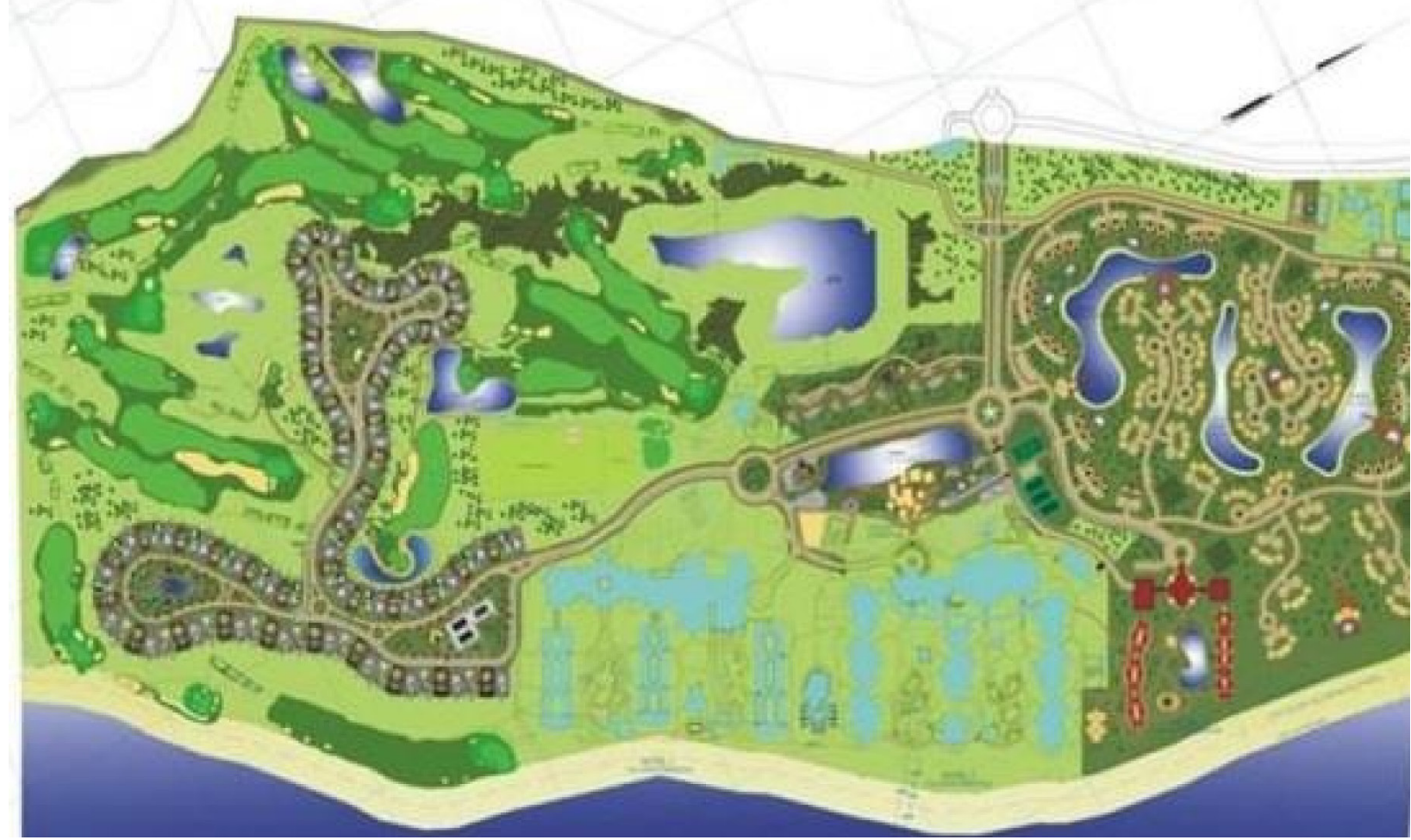

Figure 4 - Masterplan of the tourist property complex Iberostate. Mata de São João -Salvador.
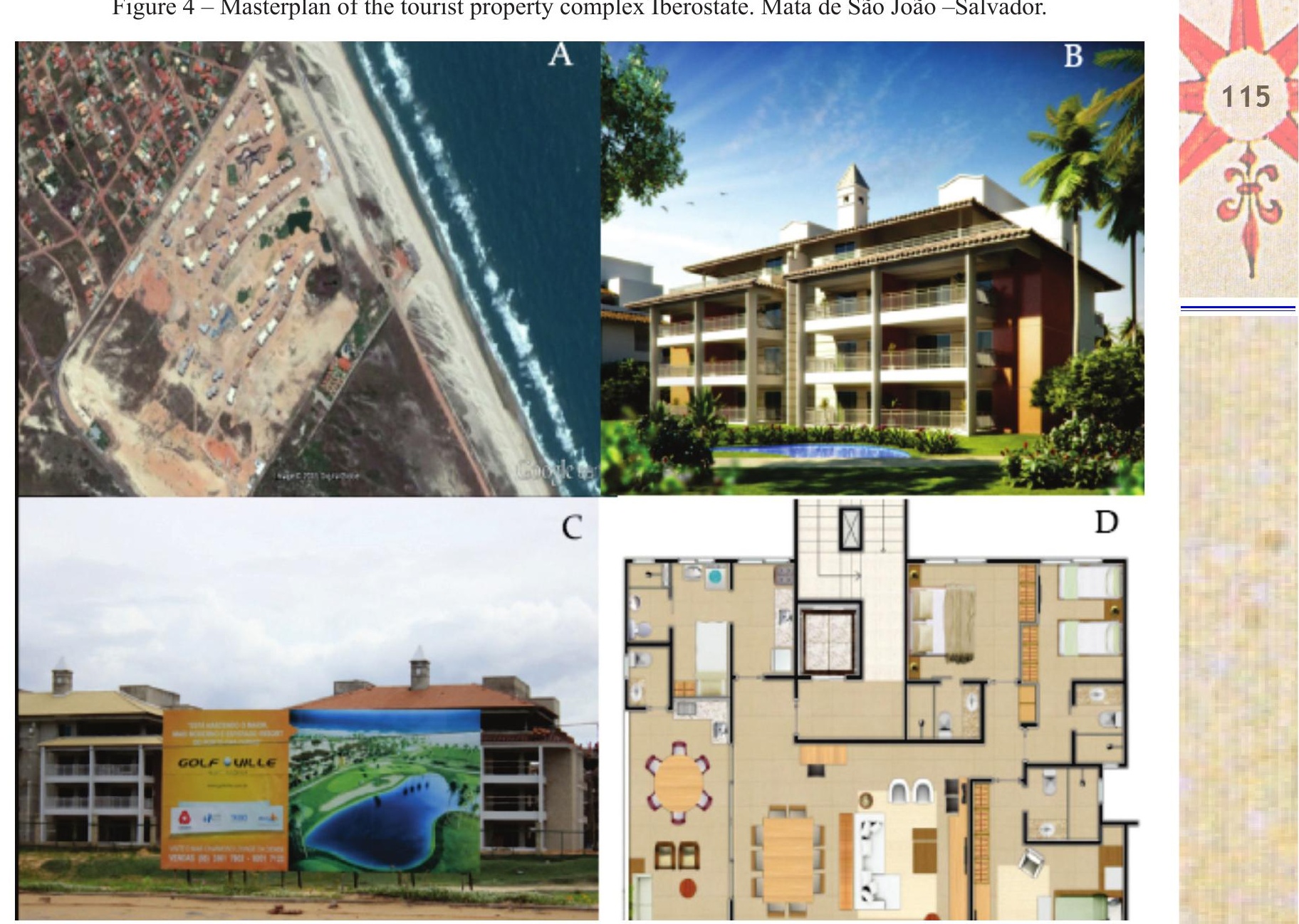
PEREIRA, A. Q.

Table 1- Homes with occasional use in the metropolitan regions of Fortaleza, Natal, Salvador and Recife

\begin{tabular}{c|c|c|c|c}
\hline \multirow{2}{*}{ Metropolitan Region } & \multicolumn{4}{|c}{ Census } \\
\cline { 2 - 5 } & 1980 & 1991 & 2000 & 2010 \\
\hline Fortaleza & 4983 & 15530 & 26564 & 39139 \\
\hline Recife & 6807 & 21968 & 31321 & 45185 \\
\hline Salvador & 10136 & 30545 & 46102 & 70502 \\
\hline Natal & 2497 & 6995 & 12963 & 25238 \\
\hline
\end{tabular}

Source: Summary of IBGE Census 1980, 1991, 2000 e 2010.

Unlike the diversity of public and private investments, the coastal sectors coordinated by the metropolis display characteristics of a precarious metropolitan urbanization in their internal urban scale. Socio-spatial problems linked to the massive growth of maritime leisure emerge associated with the spread of holiday resorts and their property derivatives. The main negative effects related to this are the excessive subdivision of the coastal ecosystems and the constant increase in land prices, even leading to the emergence of poor and irregular neighborhoods. The common contradictions in the formation of Latin American cities are also reproduced on the beach.

At an urbanistic level, one can assess fractures in the urban fabric being produced. This occurs because the technical quality of plans is restricted to the interior of complexes, meeting the "urban" demands for comfort, social ostentation and the sensation of security. The peri-urban surroundings are not considered and a diversity of scenery is created partly due to new building standards which diverge from previous designs, and partly due to new walls and barriers which do not allow direct contact with the previously existing settlements (second homes following vernacular standards and fishing communities, among others). The limited access to spaces on the seafront and the poor maintenance of the transport routes which allow circulation are strong indicators of the dislocation of the urbanistic approach, centered on private enterprise and not on the place as a whole (Figure 6).
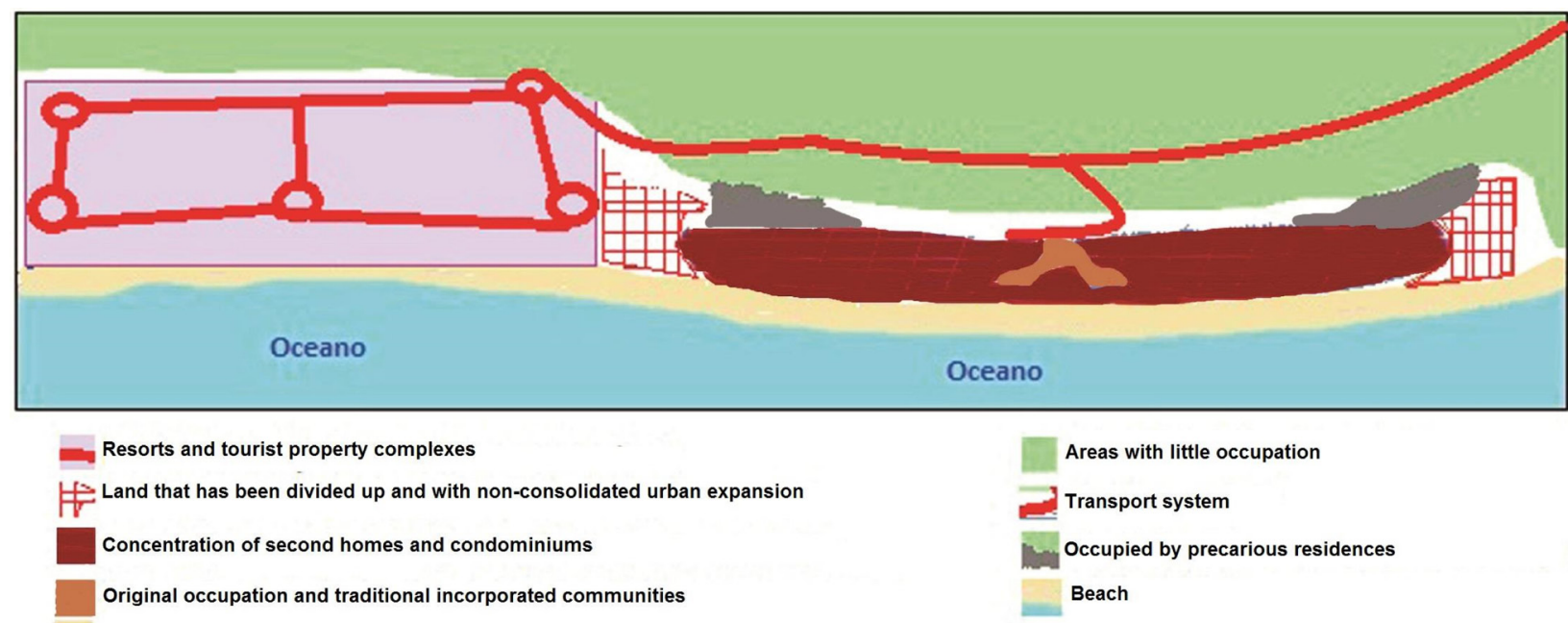

Figure 6 - Predominant forms and types on the coastal space of the metropolises of the Northeast

The metropolitan beaches, nodes on the maritime leisure network in the metropolis, continue to have the stigma of a duality of representations: attractive and repulsive. This movement has an incremental impact on the dynamic of the transformations of the peri-urban coastal space, producing fragments in the urban fabric differentiated in terms of space and time according to the social strata which they attract and/or repulse. At times these captivate as an "urban-natural" planned paradise and at others are seen as a fragment of the urban fabric which is full of precariousness. This is the model of contradictory urbanization (re)produced between what is conceived and what is lived along the beaches of the metropolis. 
Throughout the case analyzed, the process of metropolization is not defined through the cooperation of actions between municipalities. On the contrary, it has been established by the production of spaces caused by overflows and the needs generated in the central nucleus or by the demands they attract. Coastal leisure has remained in the interstices and propitiated the (re)production of urban space, even when it is not included at the center of strategic actions.

State governments corroborate the promotion of this vector of metropolitan expansion, giving continuity to the implementation of urban infrastructure, acting as intermediaries in the articulations between local, regional and international companies, promoting the "vocations" of places and granting environmental licenses for the construction of projects.

The technical aspects and establishing regulations regarding the use and occupation of the coast through enterprises that make holiday resorts viable fall significantly upon the municipalities and their (in)competences. If, on the one hand, the possibility of filling the coffers through charging urban taxes (IPTU and ITBI) appears as a significant advantage, on the other hand the demands for public services stand out and overburden the finances of municipal governments. There are observable disparities in the metropolises of the Northeast between the hub city and the remaining cities belonging to the institutional section.

The peri-urban coastal spaces are produced with new spaces directly linked to the external demands of the municipality which officially hosts them. In this sense the municipalities meet the demands generated in and by the metropolis, showing less integration and equal exchange and greater relations of dependence and hierarchy within these municipalities based on the metropolis' role as "head". The (re)production of spatial fragmentation becomes a primary reality.

Even the technical-legal documents elaborated under the responsibility of the coastal municipalities are not implemented and observed as mandated by legal precepts and duties of the public administration. The greatest example is the Urban Development Directive Plan. Derived from a descriptive technical diagnosis, the plan is transformed into a law which regularizes and provides a foundation for the present and, principally, the future of the city and the other urban spaces part of the municipality. In most cases, it covers the urban coastal spaces and those suitable for the diffusion of modern maritime practices, especially by legalizing the construction of projects and the dissemination of extensive properties, based on low demographic densities. However, there are tremendous difficulties in conducting urban structural and corrective structural programs which can correct the precarious conditions of the urban fabric. Municipalities lack the financial reserves and technical bodies capable of managing the prerogatives of the directive plans. In truth, public executives search for and praise the arrival of tourist property projects without, however, redirecting the fragmentation and the diversity of coastal locations.

\section{b. Social practices: from vacanciers towards dwellers}

The concepts through which the groups and entities define processes/activities are decisive in understanding socio-spatial transformations. This section provides evidence of how, from the formation of network-territories for coastal leisure in the metropolises, the locations acquire very distinct social contents from the single notion of a traditional community. In the constant relationship between vacanciers, place and dwellers, a diversity of social-territorial effects emerge such as: the formulation of strategies of social contact, work and division of labor and, derivatively, new forms of occupation of the coastal space.

One of the most remembered themes when discussing coastal spaces is precisely the relationship between the demands of vacanciers (tourist, excursions and resort users) and the social organization of those living in these places. Without a doubt, there is a range of criteria used to differentiate these social subjects; however, in the geographical approach to this problem the relationship with the place that they have in common contributes considerably to develop this distinction. For Cazelais 
(2009) the inhabitants are the parameter. They have the empirical knowledge of the place and a strong relationship of intimacy (self-recognition). In their self-identity the place where they live is one of the first elements that defines their social existence. On the other hand, discussions about modern nomadism and the formation of multiple territorialities are a reminder that rather than absolute conditions, inhabitants may also be transitory.

According to Cazelais (2009) the inhabitants have "la propriété morale" (sense of identification) and "la propriété foncière" (based on financial and legal instruments). If with regard to the first there is a certain consensus, this does not apply in the second case, due to the increasing global movement of purchasing residential buildings for the purpose of tourism and developing resorts. In spatial-temporal terms the definition of inhabitant and vacancier is relational. The author shares this conception when he affirms that "des villégiateurs de longue date seront quand meme considérés comme des «étrangers» par les résidents, malgréleurs efforts parfaisrépétes et soutenus pour s'intégrer". (IBIDEM, p. 182).

Lefebvre's thinking (1991) concerning daily life allows a coherent differentiation to be made between the two social subjects being evaluated. The vacanciers consider the leisure space-time as a possibility of escape from daily life, giving this situation a complementary role to their productive relations. For the inhabitants, the same space is made of a different notion of time: an ordinary notion, without surprises, part of daily obligations (work, subsistence). The need to distinguish between vacanciers and inhabitants is, in itself, part of this metropolization which makes these contacts common.

For the inhabitants, the last thirty years have seen a change from the almost complete absence of free public services to a technical approach to the territory through the installation of basic infrastructure, especially roads, means of transport and communication and electrification. However, they also admit that most of the "present day improvements" come as a result of vertical forces, and not directly as a product of their necessities.

Other improvements indicated by inhabitants refer to the economic dimension. Salaried work and monetary monthly resources are cited as gains, especially due to the possibility of increasing consumption. This is not a surprising statement considering how the inhabitants themselves affirm that it is increasingly more difficult "to seek survival" (biological and social reproduction) in their former primary and artisanal activities (fishing, crabbing, small crops and small herds of animals). Many young people are critical of the socio-occupational alternatives. The case of inhabitants of the coastal spaces of the metropolitan region of Fortaleza is presented as an example. Sample data from IBGE research (2010) indicates the importance of employment in occupations such as street salespersons, business and non-specialist service providers, among them domestic workers (janitors, cooks and general services) (Figura 7).

In the incorporated locations, the inhabitants believe in their role as supporting actors in the processes that now define their lives. The current conditions are for them the product of an externality, and they do not see in themselves the potential to define what they need and how to achieve what they desire. Empirically, they recognize the social problems that affect currently them (potential criminality, prostitution and increases in the cost of living) and see themselves as a sub-product of these socio-spatial transformation, but they turn back, immediately, to their condition as beings conducted by vertical forces.

The inhabitants recognize that as foreigners effectively become holiday resort users (especially as they are property owners) and consequently stay for longer periods of times (from weeks to months), new demands for leisure are added to the social dynamic of the new locations during distinct seasons from those practiced by local tourists and holiday resort users. While the background of these visitors and the investment taking place leads these locations to become more international, the diversity of social subjects leads to a restructuring of time in these "communities" through the different demands that have emerged. The vacanciers bring with them values and innovations, es- 
pecially in terms of clothing, sports and new vocabulary (in foreign languages) which are usually transmuted, redefined and assimilated by many when there is contact with inhabitants, especially those of a younger age range.

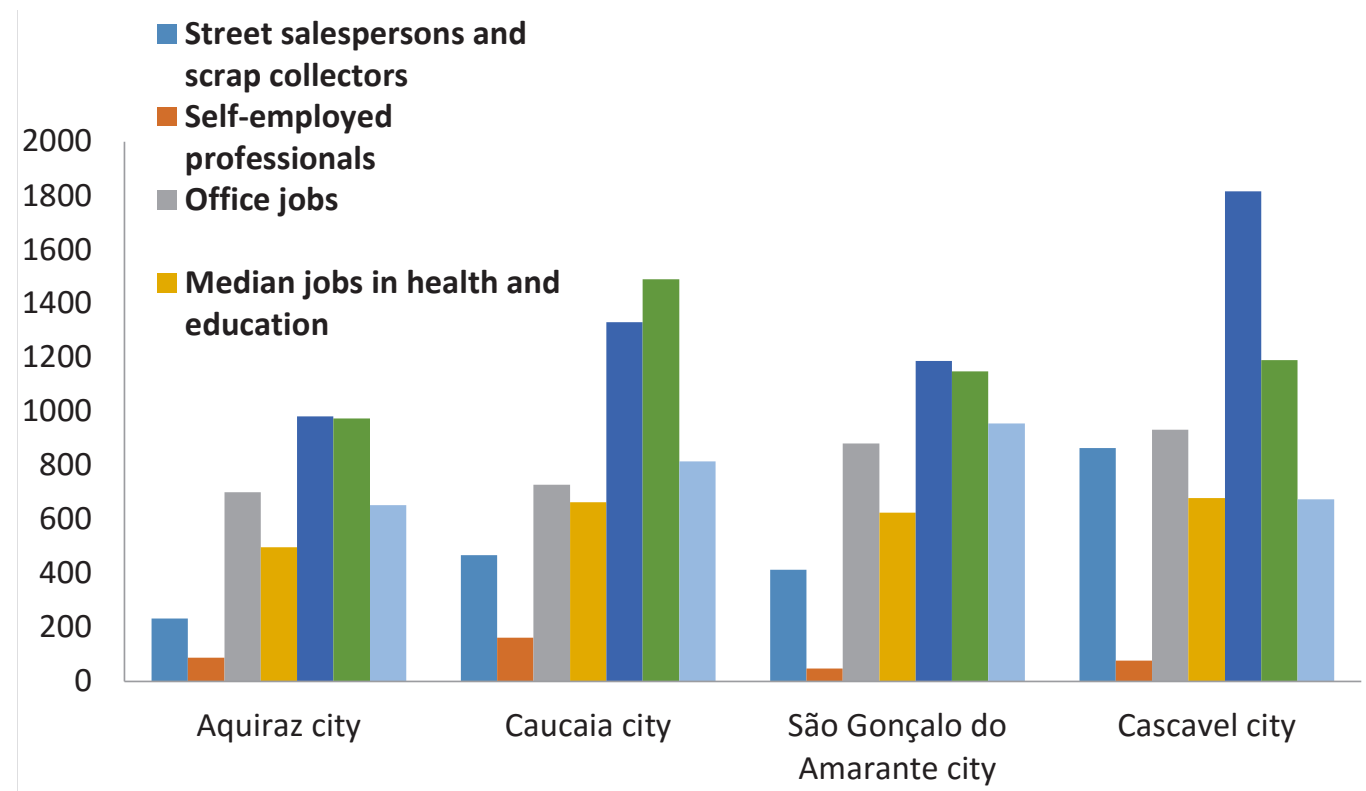

Figura 7 - Graph Main tertiary socio-occupational categories of the coastal inhabitants of the metropolitan region of Fortaleza

Source: Microdata IBGE: Metropolis Observatory, 2010.

Therefore the notion of the homogeneity of traditional communities is questioned by the formation of these locations as nodes in the coastal hub. Leisure and coastal metropolization attract migratory flows which converge to those nodes which are more dynamic in terms of employment and income and which occupy zones next to consolidated settlements. A socio-spatial diversity is promoted through inequality and the formation of social "peripheries."

In terms of the locations and the social agents which shape their dynamic at different times, the metropolization of leisure allows the formation of new territorialities, and territories with fluid frontiers and set out according to economic, social and cultural conditions.

\section{FINAL CONSIDERATIONS}

It is not hard to notice that there are spatial-temporal distinctions between settlements such as the French Riviera, the Cancun complex and the metropolitan coast of the Northeast of Brazil. The times and the wealth that materialized in the space produce varied urban densities. However, in common, there is a desire for embryonic leisure in the globalized urban society. Holiday resorts are one of the forms and contents produced and disseminated as a product of urbanity, capable of generating urban forms different from those we are used to calling cities.

The beach-city-leisure relationship in Brazil, until the first half of the twentieth century, took place mainly in a way which was internal to the urban texture of the great cities. In the last two decades of the twentieth century, and especially in the twenty-first century the spaces produced based on temporary stay (leisure, rest) encourage the expansion of the metropolitan urban fabric. In the integration between spaces, the metropolis is the decisive element in the consolidation of all the flows and settlements. Beyond the hub city the metropolis contains sub-spaces with specific and integrated characteristics and functions. In this way, the peri-urbanization of the coastal space 
motivated by holiday resorts complements and brings up to date the territorial division of labor and consumption in the internal structure of the metropolitan urban fabric in the Northeast.

On a local scale, the effects of maritime resorts are different for the nodes of the leisure network. In many municipalities in the Northeast the urban tissue consolidated on the coast is the main expression of urbanization on that particular spatial stretch. Properties destined for seasonal use, economic activities and even the seasons in these places are regulated by the demands of the metropolis(es). It is metropolitan time, free time, the bank holiday, the holidays (of non-working), which is responsible for setting the rhythm of the transformations of the seafront spaces regulated by this rationality. The metropolis mediates and attracts other flows coming from other metropolises on a national and international scale. It is the starting and ending point ... and is responsible for the distribution of flows.

The market is responsible for creating demands and tendencies/tastes (new services, hybrid tourist property enterprises, festivals, marketing, and construction of attractions) which are as diverse as possible. The State, in the Federal and State sphere, provides large financial resources for a technical approach to space and its transformation into tourist use; at a municipal level one can perceive problems concerning the regulation of land use and urbanism, the provision of collective services, dealing mainly with seasonality (which creates periods of intense demand). Those living in these peri-urban spaces, with their multiple profiles, incorporate themselves, work, criticize, live, isolate themselves and interact with the consumers of holiday resorts ... becoming greater in number. Those who use the resorts and do tourism prefer leisure and rest.

Managed in the city, this search for nature and the non-city generally is described as a factor encouraging staying at the beach and reproduces the urban life style in these places (agglomeration, simultaneity, contradictions) and thus the image of paradise is reconstructed especially by new users, inhabitants and investors who are searching ... and contradictorily, transform it into an urban space.

\section{ACKNOWLEDGEMENTS}

This text originated in reflections developed during our participation in the Fortaleza Nucleus of the Metropolis Observatory (based at the Regional and Urban Planning Laboratory- Lapur/UFC) and a research project financed by the CNPq through the Universal Edict of 2014.

\section{BIBLIOGRAPHY REFERENCE}

BEAUJEU-GARNIER, J; CHABOT, G. Traité de gégraphie urbaine. Paris: Armand Colin, 1963. BOYER, M. Les villegiatures du XVIe au XXIe siècle. Paris: Éditions ems, 2008.

BRENNER, N. Teses sobre urbanização. Revista E-metropolis. Rio de Janeiro. n. 19, ano 5, 2014. p. 6-26. CAZELAIS, N. L'espace touristique: relacions entre résidents, visiteurs et paysages. Ateliê Geográfico, Goiânia, v. 3, set/2009, p. 179-193.

DANTAS, E. De ressignificação das cidades litorâneas à metropolização turística. In: COSTA, M. C. L; PEQUENO, R. Fortaleza: transformações na ordem urbana. Rio de Janeiro: Letra Capital; Observatório das Metrópoles, 2015. p. 111-141.

DANTAS, E. W. C. Metropolização Turística Em Região Monocultora Industrializada. Mercator (Fortaleza. Online), v. 12, p. 65-84, 2013.

DEBIÉ, F. Une forme urbaine du premier age touristique: les promenades littorales. MappeMonde, v. 1, 1993. p. 32-37.

HALL, C. M.; MÜLLER, D. K. (Orgs.). Tourism, mobility and second homes: between elite landscape and common ground. Clevedon-UK: Channel View Publications, 2004.

LATORRE, E. M. Genesis y formación de un espacio de ocio periurbano: Ribamontan al Mar (Cantabria). ERIA. 1989, p. 5-17. 
LEFEBVRE, H. A revolução urbana. Tradução de Sérgio Martins. Belo Horizonte: Ed. UFMG, 1999.

LEFEBVRE, L. A vida cotidiana no mundo moderno. São Paulo: Ática, 1991.

LENCIONI, S. Metropolização do espaço: processos e dinâmicas. In: RUA, J. et al (Orgs.). Metropolização do espaço: gestão territorial e relações urbano-rurais. Rio de Janeiro: Consequência, 2013. p. 17-34.

PEREIRA A. Q. Quatro Décadas de Transformações: A vilegiatura marítima no litoral metropolitano de Fortaleza, Ceará - Brasil, Confins [Online], v.17, 2013. Acesso em: 5 ago. 2015. Disponível em: http:// confins.revues.org/8329.

PEREIRA A. Q. A urbanização vai à praia. Fortaleza: Edições UFC, 2014.

PEREIRAA. Q. Das cidades às metrópoles litorâneas: o papel da vilegiatura marítima moderna no nordeste do Brasil. GEOUSP: espaço e tempo. 2012. Disponível em: <http://citrus.uspnet.usp.br/geousp/ojs-2.2.4/ index.php/geousp/article/view/542/287>. Acesso em: 5 ago. 2015.

ROCA, M. N.; ROCA, Z.; OLIVEIRA, J. A. Expansão das segundas residências em Portugal. In: Anais do $1^{\circ}$ Congresso de Desenvolvimento Regional de Cabo Verde. Cabo Verde. 2009. p. 2448-2474.

TERÁN, F. Ciudad y urbanización en el mundo actual. Madrid: Editorial Blume, 1969.

URBAIN, J.-D. Sur la plage. Paris: Éditions Payot, 1996.

Submitted december 2015 Accepted january 2016 